\title{
Homeric Poetry and Problems of Multiformity: The "Panathenaic Bottleneck"
}

\section{Citation}

Nagy, Gregory. 2001. Homeric poetry and problems of multiformity: The "Panathenaic Bottleneck". Classical Philology 96(2): 109-119.

\section{Published Version}

http://dx.doi.org/10.1086/449533

\section{Permanent link}

http://nrs.harvard.edu/urn-3:HUL.InstRepos:3207676

\section{Terms of Use}

This article was downloaded from Harvard University's DASH repository, and is made available under the terms and conditions applicable to Other Posted Material, as set forth at http:// nrs.harvard.edu/urn-3:HUL.InstRepos:dash.current.terms-of-use\#LAA

\section{Share Your Story}

The Harvard community has made this article openly available.

Please share how this access benefits you. Submit a story.

Accessibility 


\title{
HOMERIC POETRY AND PROBLEMS OF MULTIFORMITY: THE "PANATHENAIC BOTTLENECK"
}

\author{
GREGORY NAGY
}

$\mathrm{M}$

ULTIFORMITY, according to Albert Lord, is a basic feature of oral traditional poetry. ${ }^{1}$ In his writings, lectures, and conversations, Lord preferred to use the terms multiformity and multiform instead of variation and variant in order to emphasize the fluidity of oral poetry, to be contrasted with the fixity of written texts. Lord was worried that those who are unfamiliar with the workings of any given oral tradition might easily be misled to think of its variants exclusively in terms of a preexisting fixed text:

[I]f one believes in a fixed text, then the idea of variants-even the word-indicates a deviation from a fixed entity. In one's thinking of the composition of oral traditional poetry, the word multiform is more accurate than "variant," because it does not give preference or precedence to any one word or set of words to express an idea; instead it acknowledges that the idea may exist in several forms. ${ }^{2}$

This concept of multiformity, as Lord acknowledges, challenges the student of literature with a basic problem:

Our real difficulty arises from the fact that, unlike the oral poet, we are not accustomed to thinking in terms of fluidity. We find it difficult to grasp something that is multiform. It seems to us necessary to construct an ideal text or to seek an original, and we remain dissatisfied with an ever-changing phenomenon. I believe that once we know the facts of oral composition we must cease trying to find an original of any traditional song. From one point of view each performance is an original. $^{3}$

As we see from Lord's formulation, the concept of "original" is relative in terms of oral traditions. In what follows I argue that multiformity in oral traditions likewise needs to be defined in relative rather than absolute terms.

1. A. B. Lord, The Singer of Tales (1960; $2 \mathrm{~d}$ ed., co-edited and with new introduction by S. Mitchell and G. Nagy, Cambridge, Mass., 2000), 100.

2. A. B. Lord, The Singer Resumes the Tale, ed. M. L. Lord (Ithaca, 1995), 23. In this posthumously published book, Lord also refers to his extensive discussions of multiformity in his Epic Singers and Oral Tradition (Ithaca, 1991). For more on multiformity, see also G. Nagy, Poetry as Performance: Homer and Beyond (Cambridge, 1996), esp. chap. 5, "Multiform Epic and Aristarchus' Quest for the Real Homer." The latter book (p. 9) explicitly accepts Lord's understanding of multiform while continuing to use the term variant as an equivalent. The usefulness of speaking in terms of variation-without implications of an Urform -is vividly illustrated by the metaphorical world of poikilia: see Nagy, Poetry as Performance, chap. 1: "The Homeric Nightingale and the Poetics of Variation in the Art of a Troubadour." Lord himself uses variant and multiform as synonyms in The Singer Resumes, 23: "The very existence of these thousands of variants or multiforms is dramatic proof of the fluidity of the Latvian oral daina tradition."

3. Lord, Singer of Tales (n. 1 above), 100. The italics are mine.

[@ 2001 by The University of Chicago. All rights reserved] 0009-837X/01/9602-0001\$02.00 
Let us begin by applying both synchronic and diachronic perspectives to the concept of oral composition, which can be understood as a process of recomposition in the context of each new performance. ${ }^{4}$ From a synchronic point of view, oral composition at any given time and place may be relatively more or less multiform, along a graded continuum extending from relatively more fluid to relatively more rigid systems of recomposition-inperformance; from a diachronic point of view as well, the process of oral composition may be more or less multiform at different phases of its history. ${ }^{5}$ Proposing an evolutionary model for the making of Homeric poetry, I have argued that the Iliad and Odyssey were relatively more multiform in earlier phases and relatively less so in later phases of developments that resulted ultimately in the Homeric texts as we now have them. ${ }^{6}$ The progressive reduction of multiformity resulted primarily from the passage of Homeric poetry through an Athenian phase of development-a "Panathenaic bottleneck." multiformity as applied to the Homeric poems, it is timely to reassess the evolutionary model in general and the theory of a Panathenaic bottleneck in particular.

In response to the challenge posed by Lord's concept of multiformity, the evolutionary model presents an alternative to the numerous attempts at reconstructing an "original" text of Homer. In terms of this model, we may envisage five "ages of Homer," five periods of progressively less fluidity, more rigidity:

1. A relatively most fluid period, with no written texts, extending from the early second millennium into the middle of the eighth century in the first millennium.

2. A more formative or "Panhellenic" period, still with no written texts, from the middle of the eighth century to the middle of the sixth.

3. A definitive period, centralized in Athens, with potential texts in the sense of transcripts, at any or several points from the middle of the sixth century to the later part of the fourth; this period starts with the reform of Homeric performance traditions in Athens during the regime of the Pisistratidae.

4. A standardizing period, with texts in the sense of transcripts or even scripts, from the later part of the fourth century to the middle of the second; this period starts

4. On the terms "synchronic" and "diachronic," see F. de Saussure, Cours de linguistique générale (Paris, 1916; critical ed. by T. de Mauro [with the same pagination], Paris, 1972), 117: "De même synchronie et diachronie désigneront respectivement un état de langage et une phase d'évolution."

5. For more on synchronic and diachronic perspectives in analyzing oral traditions, see G. Nagy, "Homer and Plato at the Panathenaia: Synchronic and Diachronic Perspectives," in Contextualizing Clas sics, ed. T. Falkner, N. Felson, D. Konstan (Lanham, Md., 1999), 127-55.

6. Nagy, Poetry as Performance (n. 2 above), 151-52, 109, and Homeric Questions (Austin, 1996), 103-4. This is not to say that fluidity and rigidity are necessarily characteristic of earlier and later phases of any system.

7. The term was introduced in G. Nagy, "Irreversible Mistakes and Homeric Poetry," in Euphrosyne: Studies in Ancient Epic and Its Legacy in Honor of Dimitris N. Maronitis, ed. J. N. Kazazis and A. Rengakos (Stuttgart, 1999), 259-74, esp. 271-72, and "Dividing Homer," SO 74 (1999): 64-68, esp. 68. For more on the general concept behind the term, see also id., Pindar's Homer: The Lyric Possession of an Epic Past (Baltimore, 1990), 23, Homeric Questions (n. 6 above), 43, and Poetry as Performance, 77. 
with the reform of Homeric performance traditions in Athens during the regime of Demetrius of Phalerum, which lasted from 317 to 307.

5. A relatively most rigid period, with texts as scripture, from the middle of the second century onward; this period starts with the completion of Aristarchus' editorial work on the Homeric texts, not long after 150 or so, which is a date that also marks the general disappearance of the so-called eccentric papyri. ${ }^{8}$

By the time of period 3, Homeric poetry reaches a phase that can be described in terms of "textualization"-without our having to posit an original "text." A key to this concept of textualization is the factor of diffusion, complementing the two more basic factors of oral poetics, composition and performance. ${ }^{9}$ This third factor of oral poetics, diffusion, can in some cases involve a process of centralization-even if in other cases it is a process of decentralization, of atomized dispersal. ${ }^{10}$ In period 3 of the evolutionary model, the hypothetical point of "textualization," I posit a clearly defined center for the diffusion, or "broadcasting," of Homeric poetry. The centralized diffusion would have involved centripetal as well as centrifugal forces- - "a centralized context for both the coming together of diverse audiences and the spreading outward of more unified traditions." 11 This center of diffusion was the seasonally recurring festival of the Panathenaea at Athens. For period 3, it is useful to picture the Athenian or "Panathenaic" phase of Homeric poetry as a "bottleneck" that affects the flow of ongoing oral traditions.

In terms of this metaphor of a "Panathenaic bottleneck," we may envisage a movement from decentralized multiplicity toward centralized unity. The living South Slavic oral traditions described by Lord are decentralized, abounding in a multiplicity of thematic and formal variants. A similar type of multiplicity can also be posited for period 1 in the evolutionary model for ancient Greek oral poetry and, to a lesser degree, for period 2. In period 3, however, such multiplicity becomes "gradually squeezed into a centralized unity that allows for only minimal variation." 12 In terms of the evolutionary model, only the Iliad and the Odyssey pass through the "Panathenaic bottleneck," starting in the sixth century B.C.E.; other archaic Greek epic traditions, most notably the "Cyclic" poetry of the Cypria, the Aithiopis, the Little Iliad, and the Iliou Persis, are exempt.

The wording "minimal variation" is intended to reflect an inherent relativity in the concept of multiformity: by the time we reach period 3 , in terms

8. Nagy, Poetry as Performance, 110; cf. the abridged version in Homeric Questions, 42. In Poetry as Performance, 112, I offer working definitions for my three hermeneutic models of transcript, script, scripture. In a new project, I plan to rework my definition of "period 2" in light of a forthcoming work by Douglas Frame on the Ionian cultural contexts of epic performance traditions.

9. To quote from my earlier work (Homeric Questions, 40): "I continue to describe as text-fixation or textualization the process whereby each composition-in-performance becomes progressively less changeable in the course of diffusion-with the proviso that we understand text here in a metaphorical sense."

10. For models of centralized and decentralized diffusion, see Oral Epics in India, ed. S. H. Blackburn, P. J. Claus, J. B. Flueckiger, and S. S. Wadley (Berkeley and Los Angeles, 1989), esp. S. H. Blackburn, "Patterns of Development for Indian Oral Epics," 15-32.

11. Nagy, Homeric Questions, 43.

12. Nagy, "Irreversible Mistakes" (n. 7 above), 271. 
of the model described, the multiformity of the Homeric poems is already relatively minimal. In period 4 and period 5 , the relative multiformity is even further reduced.

Whereas this model views the multiformity of the Homeric poems in relative terms, others imagine a binary opposition between multiformity and "uniformity," arguing that the Iliad and the Odyssey are uniform to start with-and positing an "original" written text in order to explain such uniformity. In the words of one commentator:

All our sources [of the Iliad] basically agree over matters of dialect, plot, episodes and so forth; other oral epics recorded in writing have a far wider range of textual variation, e.g. the Nibelungenlied, Chanson de Roland, Mahabharata or Digenes Akrites. All of our MSS [of the Iliad] somehow go back to a single origin [italics mine], and have passed through a single channel; it is improbable that more than one "original" of the Iliad ever existed, even if different rhapsodic performances and editorial interventions have led to the addition or (rarely) omission of verses here and there. This basic fixity needs to be explained. ${ }^{13}$

For this commentator, the notion of the "fixity" of the Iliad is to be explained by the hypothesis of an "original" text dictated by an eighth-century Homer. ${ }^{14}$ The evolutionary model, recalling Lord's view that "we must cease trying to find an original of any traditional song," obviates the need to posit such an "original." It sees the "fixity" of the Homeric poems as relative, resulting from a progressive decrease in multiformity, not from an "original" uniformity. ${ }^{15}$

The idea of Homeric "fixity" has led to assumptions of a rigid distinction between multiformity and uniformity, so that Lord's concept of multiformity as applied to the Homeric Iliad is rejected-while it is accepted for the Epic Cycle, as exemplified by the Cypria. ${ }^{16}$ It is worthwhile to address the assumptions inherent in such an absolutizing notion of multiformity, given the disparity between this view and the concept of multiformity as formulated by Lord. For the moment, however, let us concentrate on a contrasting concept, "uniformity."

To argue that the Iliad is "uniform" in contrast to the Cypria, which is multiform, requires a special explanation for the exempting of Homeric poetry:

\footnotetext{
It follows, then, that while [ . . ] the fixation of oral poems in writing does not necessarily affect their multiform character or produce a variant that is more authoritative than the others, [t]his conclusion fits the Cyclic epics rather than the poems of Homer [ $=$ the Iliad and the Odyssey]. Obviously, some additional factor, and not simply their fixation in writing, was responsible for the remarkable uniformity of the Homeric poems. ${ }^{17}$
}

13. R. Janko, The "Iliad": A Commentary, vol. 4, Books 13-16 (Cambridge, 1992), 29.

14. Janko, "Iliad" (n. 13 above), 37-38.

15. Nagy, "Irreversible Mistakes," 269-72.

16. M. Finkelberg, "The Cypria, the Iliad, and the Problem of Multiformity in Oral and Written Tradition," CP 95 (2000): 1-11; Janko's formulation of "fixity" in terms of an "original" uniformity is quoted at p. 4.

17. Finkelberg, "Multiformity" (n. 16 above), 9. 
The fundamental issue here is the concept of multiformity itself. What is described as "the remarkable uniformity" of the Iliad and the Odyssey could instead be viewed as a matter of relatively less multiformity in terms of these poems' evolution, as opposed to relatively more multiformity in the Cypria and in the rest of the Cycle. Multiformity and "uniformity" as polar opposites cannot simply be mapped onto oral and written poetry respectively.

What is the "additional factor" at work in making the Homeric poems distinct from the Cycle? In terms of the evolutionary model, the factor of the Panathenaea and the "Panathenaic bottleneck," beginning at period 3, is critical. Some time in the second half of the sixth century B.C.E., around the starting point of this period, the evolution of the Homeric poems diverges radically from the evolution of the Cycle. By "Homeric poems" I mean the Iliad and the Odyssey only-to the exclusion of the Cycle. ${ }^{18}$

Two important clarifications are needed.

First, in terms of the evolutionary model, only the Iliad and the Odyssey pass through the "Panathenaic bottleneck." Only the Iliad and the Odyssey pass through periods 3,4 , and 5. By contrast, the poetry of the Cycle-including the Cypria-is exempt from periods 3, 4, and 5. Consequently, the evolutionary model allows for far more fluidity - or let us say multiformity-in the case of the Cypria and far less in the case of the Iliad.

Second, if indeed the Iliad and the Odyssey were shaped by the Panathenaea, unlike the Cypria and other poems of the Cycle, we must still be wary of assuming that the Homeric poems of the second half of the sixth century B.C.E. were already the written "originals" of our Iliad and Odyssey.

With these reflections in mind, we may move from problems of "uniformity" to the related problems of multiformity. When Lord spoke of multiformity, he was thinking of oral traditions. Others are thinking of written traditions when they speak of "different versions of the Cypria through the period of one thousand years, from Herodotus in the fifth century B.C.E. to Proclus in the fifth century C.E." and when they contrast what they describe as the multiformity or fluidity of the Cypria with the "uniformity" or rigidity of the Homeric poems. ${ }^{19}$ I see conceptual and methodological difficulties with such descriptions of the Cypria as "a written multiform text."

It is striking that scholars should argue for a textual multiformity that lasts a thousand years. Such an emphasis on longue durée suggests that, in the case of the Cypria, the argument needs a stark contrast with the textual history of the Iliad, which takes up roughly the same time span. According to this argument, the Cycle in general and the Cypria in particular stayed multiform for a thousand years in contrast to the Iliad, which was supposedly "uniform" from the very start: "But there has always been only one

18. Nagy, "Irreversible Mistakes," 271. For further bibliography on the Panathenaea as the defining context of the Iliad and the Odyssey, see p. 65 of S. Lowenstam, "Talking Vases: The Relationship between the Homeric Poems and Archaic Representations of Greek Myth," TAPA 127 (1997): 21-76. Although Finkelberg ("Multiformity," 9) evidently agrees with me about the Panathenaea as a factor that distinguishes the Homeric poems from the Cycle, she chooses not to engage with my evolutionary model (more specifically, with the formulation of "period 3" and the "Panathenaic bottleneck").

19. Finkelberg, "Multiformity," 11. 
version of the Iliad." ${ }^{20}$ Yet, as argued above, the multiformity of the Cypria is not some kind of absolute: all we can say is that the Cypria was relatively more multiform than the Iliad. ${ }^{21}$ Second, there is no evidence for the claim that the Iliad was a "uniform" text dating from the second half of the sixth century B.C.E.

Moreover, there is evidence against such claims about the Iliad. The testimony of vase paintings shows clear traces of thematic multiformity in the Iliad tradition up to the early fifth century B.C.E.; to quote Steven Lowenstam: "with regard to Iliadic and Odyssean myth, the versions of the epic tradition preserved in our inherited written texts do not have authoritative status for the vase-painters of the sixth and early fifth centuries."22

We may consider the clear traces of multiformity in the textual history of the Iliad - and of the Odyssey - down to the middle of the second century B.C.E. As I have argued extensively in other works, many of the textual variants that we do find surviving in the Homeric poems are in fact the reflexes of formulaic and even thematic multiforms that characterize oral poetry. ${ }^{23}$ Such textual traces of multiformity in the Homeric poems cannot be expected to match-in degree-any corresponding textual traces of multiformity in the Cycle, not to mention the multiformity of living oral traditions as recorded by today's ethnographers. Still, many of the variants we see in the attested phases of the Homeric textual tradition are survivals of multiforms stemming from unattested phases of the Homeric oral tradition. As we work our way forward in time, to be sure, we find that the degree of textual multiformity becomes minimal. Still, even in the latest phases of the ancient textual history, it is a question of degrees: we find ever less multiformity, not absolute "uniformity."

Perhaps it would be useful for us to reverse, as it were, our temporal direction. If we work our way backward in time, not forward, as we trace the textual history of the Homeric poems, the implausibility of a "uniform" Panathenaic text of the Iliad and the Odyssey, surviving unchanged from the second half of the sixth century B.C.E. all the way to the second half of the second, can be intuited more easily. What we see is a marked increase in degrees of multiformity as we move back from the fifth to the fourth to the third periods-from "scripture" to "script" to "transcript."

20. Ibid., 11. In this context, Finkelberg compares the Homeric tradition to the Hebrew Bible, citing with approval M. L. West, "The Textual Criticism and Editing of Homer," in Editing Texts, Texte edieren, ed. G. W. Most (Göttingen, 1998), 95. In terms of my "evolutionary" model, a scriptural analogy is apt not so much for the sixth century B.C.E., as Finkelberg and West think, but more for the second and thereafter: see chap. 7 of my Poetry as Performance, "Homer as 'Scripture.",

21. See J. S. Burgess, “The Non-Homeric Cypria,” TAPA 126 (1996): 77-99, esp. p. 90, n. 51. Moreover, much of the multiformity claimed for the Cypria can be explained in other ways: it is probable that there were several or at least two compositions entitled Cypria (cf. Finkelberg, "Multiformity," p. 8, n. 26).

22. Lowenstam, “Talking Vases" (n. 18 above), 66. Finkelberg, "Multiformity," p. 9, n. 27, cites Lowenstam's article, though this citation actually undermines the general claim that she is making when she says: "no fluctuations in the names of the characters or in the order of the episodes like those observed [in the Cypria] have ever been attested for the Iliad subjects." Lowenstam documents such fluctuations (see especially his p. 66, n. 145, concerning variations on the Briseis theme and other such multiformities).

23. See esp. G. Nagy, “Aristarchean Questions," $B M C R$ 98.7.14; also id., review of M. L. West, ed., Homeri Ilias, vol. 1 (Stuttgart, 1998), BMCR 00.09.12. 
For a brief survey, let us start with the "vulgate" version of the Homeric poems, the version that Aristarchus accepted as the base text for his edition of the Iliad and Odyssey in the middle of the second century B.C.E. Even this "vulgate" was not a "uniform" text-as far as Aristarchus himself was concerned. In his Homeric commentaries or hupomnemata, he frequently adduced textual variants that he considered more likely to be Homeric than the corresponding textual forms that he actually retained in his base text, in the "vulgate." ${ }^{4}$ Similarly, though he athetized some verses-that is, marked them with an obelos to indicate that he considered them non-Homeric-he nevertheless retained such verses in his base text because the manuscript evidence at his disposal did not permit him to do otherwise. Aristarchus was persuaded that such verses, although he athetized them, really did belong in the base text that we call the "vulgate." 25

Aristarchus treated the "vulgate" Homer text in much the same way that a neo-Aristarchean editor like Origen treated the Septuagint in his hexapla edition of the Hebrew Bible: the Septuagint was Origen's base text. ${ }^{26}$ By analogy, we may say that the Homeric "vulgate," as the base text of Aristarchus, had achieved the status of "scripture."27

It was essentially the "vulgate" version of the Homeric poems, and not the textual variants adduced by Aristarchus, that survived into the medieval manuscript tradition. ${ }^{28}$ For this reason, it has been inferred that the "vulgate" version of the Homeric poems represents a textual continuum derived directly from what is supposed to be a sixth-century Panathenaic archetype. ${ }^{29}$

It must be pointed out, however, that Aristarchus himself-as frequently paraphrased in such sources as the Venetus A scholia of the Iliad-did not speak of this "vulgate" in terms of any single textual tradition. Instead, he spoke of koinai, "common" manuscripts reflecting a textual consensus that presumably went back to some kind of "standard" version. ${ }^{30}$ He spoke about plural koinai, since for him there was no single unified koine manuscript that could possibly approximate the status of a definitive archetype.

From the standpoint of classical Athenian civic terminology, koine in the double sense of "standard" and "common to all" could indeed have been used as a suitable term for a Panathenaic tradition of Homeric poetry. ${ }^{31}$ Nevertheless, such a tradition would be more a matter of performance than

24. Nagy, Poetry as Performance, chap. 5.

25. In Nagy, BMCR 00.09.12 (n. 23 above), I introduce the terms of "horizontal" and "vertical" variants: in the first case, the ancient editor had to choose between different wordings that make up a single line of Homeric poetry, while in the second case he had to choose between fewer or more lines that make up a given sequence of lines (cf. also Nagy, Poetry as Performance, 139-40).

26. Nagy, Poetry as Performance, 194-95.

27. For the hermeneutic model of Homer as "scripture," see Nagy, Poetry as Performance, chap. 7.

28. See M. Haslam, "Homeric Papyri and the Transmission of the Text," in A New Companion to Homer, ed. I. Morris and B. Powell (Leiden, 1997), 55-100, esp. 63-78.

29. Finkelberg ("Multiformity," p. 2, n. 2, and p. 10) evidently uses the term "vulgate" with this understanding.

30. Nagy, Poetry as Performance, 117, 133-34.

31. On the koine as a virtual "standard" text derived from Panathenaic competitions in performing the Homeric poems, see my Poetry as Performance, 152-56, 185-90, 193-95, 198, 205. 
of text. At best, we may think of such a Homeric tradition in terms of a Panathenaic "script." 32

Any Panathenaic "script," however, could be subject to some degree of change each time the Iliad and the Odyssey were reperformed on the occasion of each quadrennial recurrence of the Great Panathenaea. ${ }^{33}$ For an analogy, we may compare the design woven into the peplos of the goddess Athena on the occasion of each successive quadrennial recurrence of the Great Panathenaea: this design, controlled by elected officials called the athlothetai, was institutionally subject to change. ${ }^{34}$

Just as Aristarchus had no single unified koine manuscript but a multiplicity of koinai for establishing his base text, so also for us it turns out to be an impossibility to recover a single unified "vulgate," stemming from some notionally "uniform" Panathenaic text of Homer written as early as the second half of the sixth century B.C.E. ${ }^{35}$ Such a text is nothing more than a virtual reality. More realistically, we may posit multiform "transcripts" stemming from a multiplicity of seasonally recurring performances of Homeric poetry at each successive Panathenaic festival. By "transcript" here I mean a text that merely records a given performance and that has no direct bearing on the traditions of performance, as in the case of a "script." 36

It remains to ask how we may distinguish more precisely between "transcripts" and "scripts" of Homeric performances at the Panathenaea. In terms of my evolutionary model, moving forward rather than backward in time, I can only draw the line imprecisely, somewhere around the third and the fourth periods, characterized by relatively more and less fluidity or multiformity. For a more precise distinction between "transcript" and "script," however, we may look to the principle of numerus versuum, a strict system of regulating the number of Homeric verses. As the pioneering work of Michael Apthorp has demonstrated, this principle was observed by Aristarchus in establishing the base text of his Homeric edition around the middle of the second century B.C.E. ${ }^{37}$ The principle of regulating the number of Homeric verses seems to be at work already in the fourth century, seemingly as early as the time of Plato. ${ }^{38}$

As Apthorp has also demonstrated, Homeric verses that were athetized by Aristarchus nevertheless "counted": they were included in the base text of his edition. In other words, they were part of the official numerus versuum. By contrast, verses that were omitted by Aristarchus from his base text fell outside the count, as it were, and they were not part of the numerus versuum. These omitted verses, nowadays known as "plus verses," can be

32. For the hermeneutic model of Homer as "script," see Nagy, Poetry as Performance, chap. 6.

33. G. Nagy, "Epic as Music: Rhapsodic Models of Homer in Plato's Timaeus and Critias," in The Oral Epic: Performance and Music, ed. K. Reichl (Berlin, 2000), 41-67.

34. G. Nagy, "The Textualizing of Homer," in Inclinate Aurem-Oral Perspectives on Early European Verbal Culture, ed. J. Helldén, M. Skafte Jensen, and T. Pettitt (Odense, 2001), 57-84.

35. Nagy, Poetry as Performance, 117, 152-56, 185-86.

36. For the hermeneutic model of Homer as "transcript," see ibid., chap. 5.

37. M. J. Apthorp, Manuscript Evidence for Interpolation in Homer (Heidelberg, 1980).

38. Nagy, Poetry as Performance, 143. 
called "interpolations" from the standpoint of the Homeric textual tradition as understood by Aristarchus. ${ }^{39}$ They are multiforms, however, from the standpoint of the Homeric oral tradition as we understand it from analyzing the formulaic and thematic repertoire of Homeric poetry as a system. This Homeric "system" is represented not only by those textual variants that happen to fit an immediate context, established by the text of the Homeric poems as we know them. It is represented also by all textual variants that can be shown to be formulaic multiforms.

Some textual variants, that is, stem from relatively earlier phases of an evolving oral tradition, while other textual variants stem from later phases. In terms of my evolutionary model, the plus verses of Homeric poetry belong to a phase so early that they predate the system of numerus versuum. If we contemplate the later phases, when this system of verse counting was being introduced, we can see the emergence of a principle that regulates performances, not texts per se. The passage from unregulated to regulated verse counts in the performance tradition would correspond to a passage from "transcript" to "script" in the text tradition. In other words, the principle of numerus versuum had to be performative before it became purely textual. Moreover, the passage from performative to purely textual verse counting would correspond to a passage from "script" to "scripture."

The plus verses are a most valuable test case. As a rule, they do not fit, either textually or thematically: we find that there is usually something "off" about them in terms of the overall text as we know it from viewing the Homeric poems through the lens of the "vulgate" version. But there is nothing "off" about these same plus verses in terms of the overall system as we know it from viewing Homeric poetry through the lens of its formulas and themes inherited from a continuing oral poetic tradition.

A striking example is Iliad 5.808, where Athena says to Diomedes that she helped his father, Tydeus, emerge victorious in a confrontation with the Thebans. As Apthorp has demonstrated on the basis of the external manuscript evidence, line 808 was a plus verse, and had been omitted by Aristarchus from his base text, though the verse had subsequently crept back into the post-Aristarchean versions of the "vulgate," including the text of the Venetus A. ${ }^{40}$ Not only is there external evidence, in terms of a documented history of "weak" manuscript attestations, that this verse is anomalous, there is internal evidence as well, in terms of the immediate context of the Iliadic text as we have it: Athena seems to be saying to Diomedes that she is present and ready to help him fight the Trojans, whereas-by implication-she was not present and did not help Tydeus fight the Thebans. In terms of this implication, verse 808 would contradict what Athena is saying.

From the synchronic perspective of "our" Iliad, stemming from the "vulgate" version, this verse is thus an "interpolation." From the diachronic perspective, however, Iliad 5.808 is a precious vestige of a phase of Homeric

39. Apthorp, Evidence for Interpolation (n. 37 above), 47-56.

40. M. J. Apthorp, "Did Athene Help Tydeus to Win the Cadmean Games (Iliad 5.808)?," ZPE 131 (2000): 1-9. 
poetry that predates the institution of the numerus versuum at the Panathenaea. From a diachronic perspective, this verse is not at all anomalous: as we see from Iliad 4.390, Athena was indeed present and did indeed help Tydeus fight the Thebans.

Since the speaker of Iliad 4.390 is Agamemnon while the speaker of Iliad 5.808 is Athena, the argument can be made that the "focalizations" of the two verses represent an intentional contrast or even mismatch. ${ }^{41}$ True, Agamemnon's perspective is different from Athena's in the two different contexts of the text-as we have it. But the point is, we see here the building blocks of two different traditional ways of constructing the speech of Athena: she can make either a parallel or a contrast between the father and the son. In the "vulgate" version of the Iliad, she chooses to make a contrast; in another, earlier, version as reflected by Iliad 5.808, she could choose to make a parallel, just as Agamemnon makes a parallel at Iliad 4.390. We see here a glimpse of multiformity in repertoire, and the potential for different plot constructions in different times. ${ }^{42}$

In general, my earlier work has shown that the variant readings reported by the three most eminent editors of Homer at the Library of AlexandriaZenodotus, Aristophanes, and Aristarchus-stem from multiforms. The same goes for the variant readings reported by the most eminent editor of Homer at the Library of Pergamon, Crates. ${ }^{43}$ On the basis of these multiforms adduced by the ancient editors, in addition to the multiforms that survive directly in the textual traditions of Homer, I maintain that there can be no "original" version for us to reconstruct. ${ }^{44}$ The textual evidence allows us to reconstruct a Panathenaic tradition, relatively less multiform than other epic traditions, but this evidence cannot be reduced to a single "uniform" Panathenaic text.

To claim an original uniformity for the Homeric poems requires minimizing radically the multiformity inherent in the recorded textual variants. ${ }^{45} \mathrm{I}$

41. Apthorp, "Cadmean Games" (n. 40 above), 9.

42. In my earlier work on multiformity in Homeric poetry, I had put it this way (Poetry as Performance, 152): "If you accept the reality of multiforms, you forfeit the elusive certainty of finding the original composition of Homer but you gain, and I think this is an important gain, another certainty, an unexpected one but one that may turn out to be much more valuable: you recover a significant portion of the Homeric repertoire. In addition, you recover a sense of the diachrony. From [my] sketch of Homeric periodization [...], one can develop a sense of different Homers for different times, such as a relatively 'proper Homer' for the late fourth century and thereafter, periods 4 and 5 , as opposed to a 'primitive Homer' in, say, periods 1 and 2, the era before the reforms of the Peisistratidai. As for period 3, [...] the most appropriate description may be the "common' Homer-or let us say the Homer of the Koine."

43. G. Nagy, "The Library of Pergamon as a Classical Model," in Pergamon: Citadel of the Gods, Harvard Theological Studies 46, ed. H. Koester (Cambridge, Mass., 1998): 185-232.

44. For an acute discussion of multiforms attested in fourth-century "quotations" and in early papyri, see C. Dué, "Achilles' Golden Amphora in Aeschines' Against Timarchus and the Afterlife of Oral Tradition," CP 96 (2001): 33-47.

45. Such claims are reflected in assessments like the following (H. Pelliccia, "As Many Homers As You Please," New York Review of Books, 20 November 1997, 46; quoted by Finkelberg, "Multiformity,” p. 2, n. 5): "the variant recordings that we know of from papyri and the indirect sources . . . are for the most part too boring and insignificant to imply that they derived from a truly creative performance tradition. ... [W] are still left wondering if the banal repetitions and expansions that we find in various papyrus scraps really require us to accept, in order to explain them, a full-blown oral performance tradition." Once again we see an absolutizing notion of multiformity, viewed as typical of "a truly creative performance tradition" and "a full-blown oral performance tradition." In terms of the assessment just quoted, the choice is once again 
leave for another occasion an inventory of Homeric textual variants that reveal multiforms of relatively major thematic significance. ${ }^{46}$ Suffice it here to mention three examples that I have explored elsewhere:

1. A "hymnic" prooemium of the Iliad, attested by Crates, as opposed to the nonhymnic prooemium in the "vulgate." 47

2. Contexts of dual-for-plural in the "Embassy Scene" of Iliad 9, attested by Zenodotus, as opposed to contexts of dual-for-dual-only in the "vulgate"; the edition of Homer by Zenodotus regularly accepted textual variants that required dual-for-plural meanings. ${ }^{48}$

3. A "happy outcome" for the Phaeacians in Odyssey 13.152 (they are fated to escape from being sealed off forever by a mountain that threatens to envelop their city), attested by Aristophanes of Byzantium, as opposed to the "unhappy outcome" in the "vulgate" (they are fated not to escape). ${ }^{49}$

As the foregoing examples suggest, multiformity in ancient Greek epic must be understood as a matter of degrees. A more precise specification of these degrees - both formally and historically — seems a most rewarding new line of research. ${ }^{50}$

\section{Harvard University}

between oral and non-oral, multiform and "uniform"-or at least near uniform except for variants that are banal, boring, and insignificant.

46. A most significant example is a pair of variant readings in Odyssey 1.93 and 285 , attested by Zenodotus (scholia to $O d$. 3.313), where Telemachus goes to Crete instead of Sparta. Stephanie West refers to these verses as "what many would regard as the most disconcertingly suggestive of all ancient Homeric variants": see her "Elements of Epic," Times Literary Supplement, 2 August 1996, 27; cf. also pp. 43-44 of her chapter, "The Transmission of the Text," in A Commentary on Homer's "Odyssey," vol. 1, ed. A. Heubeck, S. West, and J. B. Hainsworth (Oxford, 1988). In a future project, I intend to explore further these variant readings, which I interpret as multiforms stemming from oral traditions localized in Crete. Finkelberg ("Multiformity," 10) treats these variants simply as "significant changes proposed by ancient scholars," discounting them because they did not become "part of the vulgate."

47. Nagy, "Library of Pergamon" (n. 43 above), 215-23.

48. Nagy, "Irreversible Mistakes," 259-60. See the scholia to Iliad 1.567, 3.459, 6.112, 8.503, 13.627, $15.347,18.287,23.753$; Odyssey 1.38, 8.251, as analyzed by M. Broggiato, "Cratete di Mallo negli scholl. A ad Il. 24.282 e ad Il. 9.169a," Seminari Romani di Cultura Greca 1 (1998): 137-43.

49. G. Nagy, "Reading Bakhtin Reading the Classics: An Epic Fate for Conveyors of the Heroic Past," in Bakhtin and the Classics, ed. R. B. Branham (Evanston, Ill., 2001), 71-96.

50. I record my gratitude to the following readers for their sage advice: Jonathan Burgess, Casey Dué, Mary Ebbott, Douglas Frame, Marianne Hopman Govers, José González, Olga Levaniouk, Leonard Muellner, Timothy Power, and Laura Slatkin. 